\title{
SHAKESPEARE AND THE JEWELLERS
}

(i)

The portrait with the best claim to be 'the one original' of William Shakespeare features pool-dark eyes, a thoroughly recessed hairline, pursed lips and, more controversially, an earring. ${ }^{1}$ The simple gold hoop of the Chandos portrait: eye-catching enough, but a modest trinket compared to the more elaborate confections evidently worn by aristocrats such as William Herbert, $3^{\text {rd }}$ Earl of Pembroke, or even another mere actor, a man assumed to be Nathan Field. ${ }^{2}$ Tarnya Cooper, curator of Renaissance pictures at the National Portrait Gallery, discerns a pattern. While wealthy men of the Renaissance were just as likely to wear jewellery as women, and of all types (Cooper lists 'gold chains, rings, hat badges and jeweled buttons, garters and sword belts'), earrings were favoured by people she categorises as 'courtiers and men of creative ambition', including Sir Francis Drake and Sir Walter Ralegh. Pembroke, she notes, was a keen literary patron. What lay behind the fashion? Cooper is reluctant to say: '[i]t is hard to assess what connotations single earrings may have had in the early seventeenth century'. She does add, somewhat neutrally and perhaps as a concession to body-piercers and tattooists of all periods, that it suggests 'someone who took pride in his individuality'. ${ }^{3}$

On the same subject Philip Stubbes, a Puritan writer of the late Sixteenth Century made angry by almost everything that might be classified as civilized life, minced his words archly to suggest that he knew perfectly well what it meant for a man to wear an earring. In his 1583 book, The Anatomy of Abuses, Stubbes wrote:

\footnotetext{
1 The phrase used by the antiquary George Vertue to describe the picture (now known as the Chandos Portrait) possessed by his acquaintance Robert Keck. See Tarnya Cooper, Searching for Shakespeare (London: National Portrait Gallery, 2006), p.54.

2 As illustrated in Cooper, 56.

3 Cooper, 57.
} 
Another sort of dissolute minions....are so far bewitched, as they are not ashamed to make holes in their ears, where they hang rings, and other Jewels of gold and precious stones. But what this signifies in them I will hold my peace, for the thing itself speaks sufficiently. But because this is not so much frequented amongst Women as Men, I will say no more thereof, until further occasion be offered. ${ }^{4}$

Nearly three hundred years later, J. Hain Friswell applied similar illogic, bestowing on the Chandos portrait the withering force of Victorian rectitude and getting so overheated by what he believed to be its blend of racial and sexual excess that he began to see not one earring, but many:

Once cannot readily imagine our essentially English Shakespeare to have been a dark, heavy man, with a foreign expression, of decidedly Jewish physiognomy, thin curly hair, a somewhat lubricious mouth, red-edged eyes, wanton lips, with a coarse expression and his ears tricked out with earrings. ${ }^{5}$

The horror is plain, but it stops short of Stubbes, whose interest in the love that for him dared not be named is reflected in the critical heritage of Shakespeare's Sonnets, with their apparently homoerotic reflections on the trials and satisfactions of friendship. ${ }^{6}$ The gold hoop of the portrait, now mercifully delivered from disapproval, has become something of a talisman for advocates of - in the broad theoretical sense - a 'Queer Shakespeare'.7

Firmly attached though it may have been to the playwright (and vice versa, presumably), when it comes to the question of Shakespeare's relationship to jewellery, that one small hoop of gold has arguably attracted a disproportionate level of interest, leading in extreme cases up dead ends of biographical speculation, axe-grinding and anti-history. The man's principal attachment to jewellery was in his work, and it is surprising how little attention

\footnotetext{
${ }^{4}$ Philip Stubbes, The Anatomy of Abuses (London, 1583), p...

5 J. Hain Friswell, Life Portraits of William Shakespeare (London: Samson Low, Son \& Marston), p.31.

${ }^{6}$ For a representative selection, see James Schiffer, Shakespeare's Sonnets:

Critical Essays (London: Routledge, 2000).

${ }^{7}$ See, for example, Madhavi Menon, Shakesqueer: A Queer Companion to the Complete Works of Shakespeare (Duke University Press, 2011); Unhistorical Shakespeare: Queer Theory in Shakespearean Literature and Film (Basingstoke: Palgrave, 2008).
} 
has been paid to his preoccupation with gems, rings and other lapidary accoutrements. There are notable exceptions. A fine essay by Valerie Traub detects in jewels, statues and corpses a cultural obsession with the containment of female sexuality. The literally statuesque Hermione returns from the dead cleansed of the taint of adultery; in All's Well that Ends Well, Diana refers to her chastity as 'the jewel of our house', her sale value as a bride dependent on her not forsaking to the lustful Bertram or anyone else what she represents as an heirloom ' $[\mathrm{b}]$ equeathed down from many ancestors' ${ }^{8}$ Shylock readily equates 'a diamond gone' with his runaway daughter:

A diamond gone, cost me two thousand ducats in Frankfort! The curse never fell upon our nation till now; I never felt it till not. Two thousand ducats in that, and other precious, precious jewels. I would my daughter were dead at my foot, and the jewels in her ear; would she were hears'd at my foot, and the ducats in her coffin! (III.i.72-7)

On those and other Shakespearean references to jewellery, Nancy J. Owens and Alan C. Harris take a broader semiotic perspective, showing how the rings and precious stones of the plays reflect social practices of the English Renaissance, but still with a focus on dowries and daughters. ${ }^{9}$ Katherine Gillen extends the argument beyond the household, using representations of jewellery in rape narratives to link the mythologies and actualities of Protestant purity and national economic growth. ${ }^{10}$ The most often quoted reference to a jewel in Shakespeare is, after all, John of Gaunt's metaphor for the nation: 'this precious stone set in the silver sea' (King Richard II, II.i.46). Gaunt's oblique allusion to the

\footnotetext{
8 Valerie Traub, 'Jewels, Statues and Corpses: Containment of Female Erotic Power in Shakespeare's Plays', Shakespeare Studies 20 (1988), pp.215-38; Shakespeare, All's Well that Ends Well, IV.ii.46-7, in William Shakespeare. The Complete Works, ed. Peter Alexander (London and Glasgow: Collins, 1974). All subsequent citations are from this edition.

9 Nancy J. Owens and Alan C. Harris, "'This precious stone set in the silver sea..." Literal and Figurative References to Jewellery in the Plays of William Shakespeare', Semiotica 123 (1999), pp.77-95. See also Stephen Hannaford, '”My money is my daughter": Sexual and Financial Possession in English Renaissance Comedy', Shakespeare-Jahrbuch (Bochum, 1984), 93-110.

${ }^{10}$ Katherine Gillen, 'Chaste Treasures: Protestant Chastity and the Creation of a National Economic Sphere in The Rape of Lucrece and Cymbeline', Early English Studies vol. 4 (2011), 1-38.
} 
mythological chastity of Elizabeth I emerges into stronger definition in Henry VIII when the Lord Chamberlain speculates that from Anne Boleyn 'may proceed a gem / To lighten all this isle'. (II.iii. 78-9)

Where the earring of the Chandos Portrait evokes the homoerotic, for Traub, Gillen and others jewellery is a crux for feminist critique. That pervasive focus on jewellery's evocations of sexuality has obscured a more obvious avenue for investigation: the materiality of the objects themselves as foundations of their metaphorical significance, but not for reasons rooted in the history of sexuality. By 'materiality' is meant not just objects but processes of production. Jewellery and fine metal-working were conspicuous industries in Early Modern London, subject to regulatory pressures not unlike those that bore upon the newly professional theatre, as well as to longer-term shifts in demand. Viewed inclusively, the language of jewellery we find in Shakespeare's plays responds subtly to those changes and in ways that mark it out as distinct from that of his contemporaries. Carrying the work of jewellers in his left ear, Shakespeare carried their anxieties into his own work.

Not only their work. The jeweller who appears as the last of three artists or artisans in the first scene of Timon of Athens focuses attention on Shakespeare's particular interest in his product. The nameless character is, granted, less a craftsman than the latest in a succession of toadying philosophers, caught between disquisitions on value and gross flattery:

TIMON: Sir, your jewel Hath suffered under praise.

JEWELLER: What, my lord! Dispraise?

TIMON: A mere satiety of commendations: If I should pay you for't as 'tis extoll'd, It would unclew me quite.

JEWELLER: $\quad$ My lord, 'tis rated As those which sell would give; but you well know Things of like value, differing in the owners, Are prized by their masters. Believe't, dear lord, You mend the jewel by the wearing it.

TIMON: Well mock'd. (I.i.167-176)

If the jeweller routinely contends that judgments of value are subjective, Timon's reflection on his jewel is profoundly ironic. Imagining a world where the 
monetary value of an object is equal to the worth people bestow by praising it, he hypothesizes his own ruin: 'it would unclew me quite'. But he goes on to experience the tragic knowledge that the only thing that could save him would be such a world, in which money really did follow the language of promises and obligations; itself, of course, a state of affairs likely to lead to the sort of rampant inflation England experienced in the early Seventeenth Century. ${ }^{11}$ The jeweller's flattering conclusion compounds the irony. On the face of it, he simply means that Timon resolves any imperfection in the piece by wearing it. To Timon, that is 'mockery' because he sees through the jeweller's charm, yet to wear the jewel at all is both a badge of extravagance and a walking demonstration of how monetary and discursive value are skidding invisibly out of synch. It will not, like some lapidary prophylactic, save him from ruin, because it really is not worth as much as he needs. Mockery indeed: he may 'mend' the jewel, but the jewel cannot mend him.

That suggests a further point of departure from previous studies, which highlight what might be described as the jewel's symbolic integrity, its guarantee of purity. Timon of Athens asks us to contemplate the disturbing prospect of its inauthenticity - its 'mockery' - in relation either to perceived value or actual substance. Lurching from riches to poverty, Timon's world flips between substance and fakery. At the end of the banquet in which The dishes are uncovered and seen to be full of warm water, (III.vi.85) the fourth of the attendant lords remarks, 'One day he gives us diamonds, next day stones'. (III.vi.120-1) The word choice is partly determined by the trite rhyme with the Third Lord's observation that he feels Timon's madness in his bones, but there is a subtle play on terms that redoubles the effect of the Fourth Lord's syntax. As a contrast with 'diamonds' we expect something more unambiguously valueless than 'stones'. Encountering the word, so often a synonym for 'gems', we find its face value disappearing before our eyes. Even when they are authentic, gems may prove to be merely false representations of something else. In the nightmare before his death, Clarence sees

${ }^{11}$ For an excellent account, see Joan Thirsk, Economic Policy and Projects. The Development of a Consumer Society in Early Modern England (Oxford: Clarendon Press, 1978), pp.15-16. 
dead men's skulls, and in the holes

Where eyes did once inhabit there were crept,

As 'twere in scorn of eyes, reflecting gems,

That woo'd the slimy bottom of the deep

And mock'd the dead bones that lay scatter'd by. (Richard III,

I.iv.28-33)

As in Timon, this 'mockery' is a belying of surface appearance. Where there should be eyes, there are gems; where there is manifest death in the shape of mud and skeletons, Clarence sees the mocking illusion of life. Incapable of the real act of seeing, those gems merely reflect their surroundings. However authentic they may appear to be, they prove fakes.

The passage from one to the other is not inevitable. In Pericles, Thaisa eyes up the visiting hero, musing that 'All viands that I eat do seem unsavoury, / Wishing him my meat', (II.iii.31-2) before concluding that he is 'like diamond to glass', (II.iii.36) the real thing set against the succession of fake men she has come across before. All's Well that Ends Well lives up to its name partly because Diana is able to invoke as surety that bastion of respectability, 'The jeweller that owes the ring' whose presence prompts the King to threaten her with prison until he understands her part in the righteous trick played on Bertram. (V.iii.290) In The Merchant of Venice, however, the whole business of determining the value of precious metals is turned upside down, thanks to what looks like familiarity with the ways of jewellers. The Prince of Morocco falls into an obvious moral trap: how can the jewel that is Portia be set in the second-class metal that is silver? 'Never so rich a gem / Was set in worse than gold' (II.vii.534) he concludes, with the authority of a connoisseur. His lapidary expertise does him little good. When he opens the golden casket there is no sign even of Clarence's fake eyes, but only 'A carrion Death, within whose empty eye / There is a written scroll' with the warning that 'All that glisters is not gold'. (II.vii.63-5). It is both a rebuke to jewellers and a warning to them to be on their professional guard against fraud. 
In Shakespeare's London they had every reason to be. In 1601 a Bordeaux jeweller called Augustin Hiriart visited the city, claiming to be a master counterfeiter of precious stones. ${ }^{12}$ By means not entirely clear, he gained an introduction to the Secretary of State himself, Robert Cecil, who wondered whether it was possible to fabricate rubies. Initially Hiriart thought not, but undertook to experiment. He returned to France, travelled to Italy, and after four years wrote to Cecil to announce his success: he had made rubies of 'the greatest possible perfection', so good that the 'cleverest jeweller' would value them at no less than $£ 3000$ each. He then offered Cecil a sample for $£ 300 .{ }^{13}$ Whether Cecil took up the offer is not known.

The Goldsmiths' Company was constantly on the lookout for counterfeit practice: in joining, members took an oath not to engage in forgery. ${ }^{14}$ In 1608 their ability to control malpractice was sorely tested by one of their own members. Thomas Sympson of Cheapside was suspected of faking jewels and setting them in gold. His house was searched by order of the Company and the party found a large store of stones which Sympson had previously shown off to colleagues 'affirming them to be right whereas in truth they were counterfeit and no worth'.15 An inquiry was established, a range of workmen interviewed, and the report lodged on 8 October 1608. Sympson was determined to have a team of seven jewellers working on 'crystals and other stones of no worth' in order to make them look like rubies. True stones of equivalent cut and mass would, the inquiry reckoned, be worth 'upwards of $£ 7000$ to $£ 8000$ '.

It was not only in the techniques of forgery that Sympson had expert knowledge. He had an international distribution network planned, with the intention of keeping the Company's prying eyes at bay. The inquiry found that he had been in contact with the governor of the Turkey Company, Sir Thomas Lawe, about marketing his produce in the Mediterranean and even approaching the Sultan, Ahmed I. One of the pieces promised had been, Sympson claimed,

\footnotetext{
12 As recounted in Hazel Forsyth, London's Lost Jewels. The Cheapside Hoard (London: Museum of London, 2013), p.68.

${ }^{13}$ Letter from Augustin Hiriart to Robert Cecil, in the Cecil Papers, August 1604, Calendar of the Cecil Papers in Hatfield House, vol 16 (1604), undated holograph, 1p. (108.110), cited in Forsyth, p.68.

14 Forsyth, p.72.

15 Goldsmiths' Company Court Minutes, 0 fols 588-90, cited in Forsyth, p.68.
} 
'rescued' from a church in France. ${ }^{16}$ Further investigation followed. Other goldsmiths and jewelers came forward to testify, giving the names of those who had worked to Sympson's instructions. One was the French jeweller of Blackfriars, Leonard Renatus, who had cut twenty-nine stones for Sympson and drilled many others so that they could hang as pendants or earrings. The results were so convincing that members of the Company struggled to distinguish them from the real thing; in one case, a lapidarist called Haunce Nicasius failed to recognize his own handiwork. ${ }^{17}$ Sympson was, naturally, keen to keep his team of jewellers in the dark, paying them to prepare the settings and craft the raw crystals before taking them away himself for colouring. His recipe remained a closely guarded secret. Like Augustin Hiriart, he even approached and, it seems, impressed Robert Cecil with his skill, though not necessarily with his morality. ${ }^{18}$

Outraged, the Company declared that Sympson had brought 'disgrace and discredit...indignity and scandal upon them', and sent the Beadle to Cheapside to arrest him. But Sympson was a violent man as well as a cunning one. He resisted with force, made 'slanderous and irreverent and insufferable speeches', declared his intention of quitting the Company, and made 'a violent escape'. The Company Court duly decided to expel him, threatening criminal prosecution either by the Mayoral Court or the Star Chamber itself. It appears their bark was worse than their bite. When Thomas Sympson died in 1633 he was described as 'One of His Majesty's Jewellers' and worth five thousand pounds. ${ }^{19} \mathrm{He}$ left another legacy. In 1614 factors of the East India Company were disciplined for selling fake rubies, so causing 'the [local] people to hate and detest us' and bring 'discredit and embarrassment to the nation'. Sympson's labours encouraged the suspicion abroad that 'the precious stone set in [a] silver sea' that was England was merely a fake. ${ }^{20}$

In spite of this conspicuously homemade scandal, the Goldsmiths' Company was certain that it could lay the blame for counterfeiting further afield. In 1622 the Wardens wrote to the Solicitor General, Sir Robert Heath,

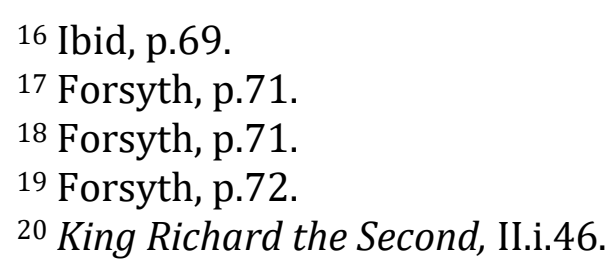


complaining of the widespread practice of counterfeiting precious stones. They appended a list of 183 immigrant goldsmiths who were said to be making fake rubies and so diminishing the livelihoods of indigenous craftsmen. What the Company saw was a broader process of corruption in which the theft of real gold, re-smelting and the degradation of alloy standards all played a part. Worst of all, failure to address the abuses could be traced to the presence of known forgers among the Court of Wardens, enemies within state regulation. Since the Company could not sort out its affairs, a Crown review was deemed necessary. Lord Coventry duly submitted a report to Parliament in October 1634. There was no point, he concluded, in banning the import or export of counterfeit jewels; it would equally be a waste of resources to encourage people to buy only the real thing; it was, he thought, an insult to people's intelligence to suggest that they were taken in by fakes. The matter was, ultimately, one of trading standards rather than craftsmanship, over which the Goldsmiths' Company already exercised sufficient control. ${ }^{21}$ Not surprisingly, Coventry's conclusions were disputed, and in 1636 a royal proclamation declared the wearing and exporting of fake stones illegal. ${ }^{22}$

It is reasonable to speculate that Shakespeare was drawn to the contradictions of jewellery because they so much resembled those of the theatre, another industry that thrived on drawing lines between the real and the imaginary, and attracting anxieties to suit. In both cases, it may be argued, the deeper-lying anxiety of observers was about modernity itself: a fear of the rapidly expanding city with its pursuit of luxury, its flouting of traditional hierarchies of behaviour, its improvisation of new protocols, its international diversity and, above all, new ways of making money. All those anxieties found rich expression in Ben Jonson's 1610 The Alchemist, whose counterfeiting antiheroes incur the justice Thomas Sympson evaded.

${ }^{21}$ Calendar of State Papers Domestic: Charles I, 1625-49, ed. John Bruce (London, 1864), vol 8, p.534 (October 1634), cited in Forsyth, p.76.

${ }^{22}$ Calendar of State Papers Domestic: Charles I, 1635-6, ed. John Bruce (London, 1864), vol 10, p.317 (March 1636), cited in Forsyth, p.76. 
If the situation of the theatre drew Shakespeare to the language of jewellery, one of his favoured subjects cemented the attraction. The most prominent way in which jewels and fine metal feature literally in Shakespearean performance is in objects of state: crowns, sceptres, rings. If he is to convince, a stage king needs the trappings of kingship as much as a real king, and the correspondence of theatre between palace and playhouse has been a path well trodden by critics for thirty years. ${ }^{23}$ It goes with a radical anxiety about the role of emergent professional theatre in society more broadly conceived. Another puritan writer of the outraged 1580s, Stephen Gosson, worried that actors undermined the whole social hierarchy because they were so good at imitating their betters:

If private men be suffered to forsake their calling because they desire to walk gentlemen-like in satin and velvet, with a buckler at their heels, proportion is broken, unity dissolved, harmony confounded. ${ }^{24}$

How much more dangerous was it to see an actor taking on all the manners and trappings of a divinely appointed king, whose authority might therefore be thought to reside not in God's will but that the royal tailors and jewellers. In the deposition scene from King Richard II the anxiety reached its height. Improvising a kind of reverse coronation ceremony, Richard surrenders power just as many were muttering that the ageing and heirless Queen Elizabeth should. 'I am Richard II', she is reputed to have said, and the scene in question (perhaps the biggest professional risk Shakespeare ever took) was duly suppressed:25

Now mark me how I will undo myself: I give this heavy weight from off my head And this unwieldy sceptre from my hand The pride of kingly sway from out my heart...(IV.i.204-7)

\footnotetext{
${ }^{23}$ See, for example, Leonard Tennenhouse, Power on Display. The Politics of Shakespeare's Genres (London: Methuen, 1986).

${ }^{24}$ Stephen Gosson, Plays Confuted in Five Actions (London, 1582), G7v.

25 See, among many other accounts, Park Honan, Shakespeare. A Life (Oxford: Oxford University Press, 1998), p.217; Duncan-Jones, pp.147-8.
} 
Characteristically for Shakespeare, the authenticity of the object is realized not only through its material existence as a prop but through the use of deictics and personal pronouns that foreground the indisputable presence of the actor's body: 'this heavy weight', 'my head', 'this unwieldy sceptre', 'my hand'. But there is equal persuasion in the way Richard turns the speech to an inner world we cannot see. The objects are significant - dangerously authentic - not because they are outwardly perceptible, but because they are rooted in what might be called emotional identity: 'kingly sway' lives in the crown, but most profoundly of all in the king's heart.

Shakespeare had rehearsed the theme in 3 Henry VI but to different effect. Disguised, with a prayer-book, the defeated King Henry gives himself away to a pair of game-keepers who mistake the trappings for the man. '[I]f thou be a king, where is thy crown?' asks the second Keeper with a certain Monty Python-like simplicity. (III.i.61) Henry responds by directing the two men to the new kind of kingship he has discovered, a kind that eludes Richard II even as it anticipates his language of jewels and inner feeling:

My crown is in my heart, not on my head;

Not deck'd with diamonds and Indian stones,

Nor to be seen. My crown is call'd content;

A crown it is that seldom kings enjoy. (III.i.62-5)

Henry re-interprets benignly the schism of person and trappings that Richard instantly grasps as a disaster, so finding temporary solace in it before discovering that it leads, as for Richard, to prison and death.

That troubled correspondence of jewels and emotional life is a dimension missing from existing narratives of objects and crafts in the period, which tend either to explore a museological fascination with items Shakespearean audiences did not actually see, or to stress the discontinuity between perfected craft and imperfect playacting. ${ }^{26}$ What we find in the plays is infinitely more nuanced and

26 The trend in what might be termed 'object criticism' began with Lisa Jardine's Worldly Goods (Basingstoke: Macmillan, 1996) and reached its apotheosis in Neil McGregor, A History of the World in 100 Objects (London: British Museum, 2010), Jane Birkett, Shakespeare in 100 Objects (London: Nick Hern Books, 2014), and Jonathan Bate and Dora Thornton, Shakespeare: Staging the World (London: 
less predictable than historical narratives might suggest. The metaphorical and emotional life of objects is what interested Shakespeare, his actors and us, the audience: a reality, in other words, more vivid even than the objects audiences did see, the constantly recycled, slightly ramshackle nature of the items listed in the inventory of theatre manager Philip Henslowe ('1 Pope's mitre; 3 imperial crowns; 1 plain crown; 1 ghost's crown; 1 crown with a sun; 1 black dog; 1 cauldron for the Jew'). ${ }^{27}$ While Henslowe's list of clothing suggests items indistinguishable from those that might be worn at court by any young man posing languidly for a miniature - satin cloaks with gold lace, velvet caps embroidered with gold spangles, a scarlet cloak with buttons of gold, faced with blue velvet - 28 theatre companies knew that the eye must work in tandem with the ear and the nerves in accepting the reality of the performance.

Overall it is striking how little Shakespeare was preoccupied with the kind of gems set forth by what might be called 'object criticism'. Jonathan Bate and Dora Thornton's Staging the World describes two items that appear to hover in the filthy air surrounding Macbeth. The Glenorchy Charmstone and the Ballochyle Brooch were used, respectively, for the curing of murrain in cattle and the working of witchcraft upon humans or animals. They are rock crystals mounted on silver (the Prince of Morocco would have approved of the matching of second-string items). Staging the World sees them as representing 'everything James [I] found ungovernable' in the Highlands and Islands, symbols of superstition and clan loyalty. ${ }^{29}$ This suggests that the association of jewels and magic was confined to the margins of the country, whereas in fact it was widespread and metropolitan, for good reasons. Thomas Phaire warned readers to

British Museum, 2012). Chloe Porter, Making and Unmaking in Early Modern Drama (Manchester: Manchester University Press, 2013), explores the paradox that representations of craft on the Renaissance stage merely expose the imperfection of plays, as set out in Tiffany Stern and Simon Palfrey, Shakespeare in Parts (Oxford: Oxford University Press, 2007).

${ }^{27}$ As presented in Andrew Gurr, The Shakespearean Stage 1574-1642, $3^{\text {rd }}$ ed. (Cambridge: Cambridge University Press, 1992), p.188.

28 Gurr, p.195.

${ }^{29}$ Bate and Thornton, pp.204-5. 
Bear about you precious stones (if you have them), specially a jacinth, a ruby, a garnet, an emerald or a sapphire, which has a special virtue against the pestilence, and they be the stronger if they be borne upon your naked skin, chiefly upon the fourth finger of the left hand, for that hath great affinity with the heart. ${ }^{30}$

The magus Simon Forman followed suit, wearing a gold and coral ring on the little finger of his left hand for protection against a formidable list of adversaries including witchcraft, satanic possession and thunderstorms, but more generally to increase his fame and 'overcome enemies' ${ }^{31}$ It was not uncommon to wear toadstones (a form of fish tooth) and bezoars (goat stones) as a warning against poison; the pieces in question were said to change colour when the threat was near. ${ }^{32}$ More generally, jewellery featured among collections of relics, as in Father Oldcorne's oculary. By reverse logic, precious stones were recognized not just as preventers of harm but as agents of it, a belief reflected in the poisoned pearl - a 'union' by virtue of its singular merit - which Claudius adds to Hamlet's cup (V.ii.264). The medico-magical properties of jewels were, in other words, at least as much in evidence during the period as (and partly because of) their commercial value.

It is hard to name another such instance in Shakespeare's work. Uniquely valuable and poisonous in the play, Claudius's union is unique in his creator's oeuvre. In other respects too, Shakespeare was singularly uninterested in what attracts modern historians to the business of jewellers. Revolutions in diamond cutting during the 1590s left no obvious mark on his plays. Only twice did he use the term that indicates a minimal cognizance of the business of goldsmiths: 'here's the note / How much your chain weighs to the utmost carat', offers the goldsmith Angelo in The Comedy of Errors (IV.i.28-9); Prince Hal protests his innocence to his father by saying that gold less pure than went into the crown, 'less fine in carat', is more precious because less of a drain on health and life (IV.v.162). Even Shakespeare's occupancy of lodgings in Silver Street happened

30 Thomas Phaire, A Treatise of the Pestilence (London, 1560), p.12.

${ }^{31}$ Cited in Barbara Howard Traister, The Notorious Astrological Physician of London. Works and Days of Simon Forman (Chicago: The University of Chicago Press, 2001), p.31.

${ }^{32}$ Liza Picard, Elizabeth's London. Everyday Life in Elizabethan London (London: Weidenfeld and Nicolson, 2003), p.160. 
after the silversmiths had left; precious metalworkers had long before ceded the area to wigmakers. ${ }^{33}$

There are, however, themes in the history of jewellery that offer more promising scope. In her 1970 survey of the subject, Joan Evans describes a paradigm shift in the wearing of jewellery between the early Sixteenth and late Seventeenth Centuries: in other words, symmetrically enclosing Shakespeare's writing life. Jewellery begins that long period principally as a male artifact, making use of emblems that express political or cultural power. By the end, in Evans's narrative, it has become predominantly a female artifact, expressive of no power except that of money (usually the husband's). ${ }^{34}$ Portraits across the period do not always support Evans's narrative, which still asks an intriguing question about Shakespeare. In what respect do his references to jewels endorse a disappearing reality of male ostentation, and how far do they seize upon an emerging one of female luxury?

Thanks to corpus linguistics technology, it is easier than ever to identify where those references lie and to see the patterns of use behind them, and not just in the works of Shakespeare. The Bible presents an interesting contrast. Since the 1562 Geneva translation was one of the principal texts Shakespeare was brought up on, we might expect its language of jewellery to be reflected in his works. References to jewels are confined to the Old Testament: not surprising, perhaps, since it is largely a narrative of nation-building by divinely appointed kings, whereas the New Testament records a world dominated by foreign power in which new virtues of humility and charity replace the splendours of the race of David and Solomon. The most prominent pattern emerges from the Temple of Solomon and the Song of Solomon, where jewels are tokens respectively of divine magnificence and of female erotic power, the latter

33 Katherine Duncan-Jones, Shakespeare. An Ungentle Life (London: Methuen, 2010), p.239.

34 Joan Evans, A History of Jewellery, 1100-1870 (New York: Dover, 1970). 
in contrast to the works of Shakespeare's other main literary influence, Ovid, whose precious stones and pearls are frequently symbols of chastity. 35

Corpus technology makes it easy to do something else: count. So, here are some statistics. The word 'jewel' occurs 63 times in 32 works by Shakespeare; the plural form 33 times in 19 works, with a smattering of variant forms. For reasons metaphorical or literal, individual items feature as follows: 'ring', 159; 'pearl', 27; 'diamond', 15; 'bracelet', 7; 'crown', 265; 'sceptre', 30. But Shakespeare was drawn more often to gold than to any other precious substance: that word appears 233 times in his works, and 'golden' a further 106 times. Here the focus is on the term 'jewel' and its plural form, with occasional forays into diamonds and pearls: an exercise in undifferentiated symbolism that admittedly skates over the individual resonances of particular kinds of precious stone. Terms that should be synonymous with it, such as 'stone', are used in their more usual sense - and once in direct opposition to the lapidary meaning, as in the instance from Timon of Athens cited above - with the single exception of John of Gaunt's 'precious stone' that is Britain (II.i.46). But the differentiation within that general category is fivefold: as prop or identifier; as masculine value; as feminine value; as reference to monetary value; and as soul or life. That pattern is largely shared by the sub-categories of 'pearl' and 'diamond' but with exceptions. Shakespeare draws the conventional parallel between pearls and tears, and frequently uses an abundance of pearls to signify riches or royal favour. ${ }^{36}$ There is a further distinction here. Where pearls as tears occur exclusively in early works, with King John the decided outlier, pearls as riches are found from The Taming of the Shrew right through to Henry VIII but with increasing frequency towards the later years of Shakespeare's career. It is not willfully biographical to suggest that where he outgrew juvenile literary metaphors, he found visions of lavish riches ever more compelling.

\footnotetext{
35 E.g. The Song of Solomon 6.14-15; 1 Kings 10.1-21.

${ }^{36}$ For tears, Venus and Adonis, l.1001; King John, II.i.465; The Two Gentlemen of Verona, III.i.224; Richard III, IV.iv.321-2; Sonnet 34, l.13; The Rape of Lucrece, l.1263. For riches or royal favour, Antony and Cleopatra, II.v.45-6; Much Ado About Nothing, III.iv.17; Henry V, IV.i.258; Henry VIII, IV.i.37 (Stage Direction for the Order of the Coronation); The Taming of the Shrew, Induction, ii.40 etc.
} 
When used as props, Shakespeare's jewels are often signs of error. In Twelfth Night Olivia sends a ring for Viola, thinking she is a man (I.v.285); the mistake is rectified only when Sebastian has the certainty of Olivia's pearl in the palm of his hand (IV.iii.2). In Love's Labours Lost the King mistakes Rosalind for the Queen, knowing her 'by this jewel' (V.ii.455). Angelo the goldsmith in The Comedy of Errors is pursued for debt because his gold chain has gone to wrong Antipholus (IV.i.1-70). Such mistaken 'pledge[s] of affection', as the phrase goes in 1 Henry VI, (V.i.47) reach their height in The Merchant of Venice, where Bassanio gives away his engagement ring to the young lawyer who turns out to be his fiancée, Portia, in disguise (IV.i.447-8). If these jewels are meant as guarantors of identity, they are highly unstable ones, symbols that obscure as much as they reveal. As such they are like actors: fakes, and very hard to distinguish from the real thing.

Shakespeare deployed a rich language of jewellery as, at the conservative end of Joan Evans's historical spectrum, emblems of male valour. Cleopatra laments what she calls the theft of her 'jewel', Antony (IV.xiv.78). When Coriolanus is laying waste to the enemy city whose destruction will give him his name, his general, Titus Lartius, claims that 'a carbuncle entire [in the sense of a ruby or garnet], as big as thou art, were not so rich a jewel' (I.iv.57). In Richard II, Mowbray longs to fight Bolingbroke and defines 'a bold spirit' as 'a jewel in a tentimes barr'd up chest' (I.i.180). Having a good reputation as a man, we're assured in Othello, 'is the immediate jewel of [our] souls' (III.iii.160). Yet there is something tainted about all these examples. The lustre of Antony's jeweldom had all too evidently departed long before his death. Coriolanus's jewel-like qualities evoke an impossible desire for perfection that make him a disastrous and ultimately treasonous politician; Shakespeare's only previous use of the word 'carbuncle' was in its other sense of an ugly, malignant growth, with King Lear describing his eldest daughter as 'a boil, / A plague sore, an embossed carbuncle / In my corrupted blood' (II.iv.224), which is just what the jewel of a man Coriolanus becomes to his home city of Rome. Mowbray's fight with Bolingbroke never happens because the King arbitrarily dissolves it; so much for bold spirits. In Othello, it is the Iago who proclaims the virtue of having a good name because he needs it to disguise his own ill intentions and to persuade 
Othello that he is irreparably sullied by his wife's imaginary adultery. Even Lamord, the Norman fencer referred to in Hamlet, 'a brooch indeed / And gem of all the nation', is invoked as an inspiration to foul play (IV.vii.93-4).

In Cymbeline it is the villain Iachimo who, Iago-like, plays on Posthumus's mind by constantly likening his fiancée Imogen to a jewel, as though to infiltrate the erotic associations of the Song of Solomon into an image often used to represent female chastity. ${ }^{37}$ The repeated dwelling on the diamond that once belonged to Imogen's mother points to a generational trading of assets between men (I.i.134-62). This is the territory expertly charted by Valerie Traub: as in Cymbeline, or indeed in the Petrarchan sonnet tradition, the jewel frequently hovers as a symbol between purity and desire, a pattern seen in As You Like It, Romeo and Juliet and Much Ado About Nothing, where images of jewellery evoke but set out to control the threat of female sexuality. But it is characteristic of Shakespeare that he should suddenly shake up such relatively conventional uses with a literalism that turns out to be full of inferred associations. Duncan presents Lady Macbeth with the 'diamond' he fatally supposes represents her. In Henry VIII, Katharine of Aragon is 'like a jewel' because 'she has hung twenty years about [the King's] neck', which brilliantly captures her physical devotion to him, his frustration with her (for 'jewel' read 'millstone'), and the public fact that her grace, dignity and pedigree adorn him in a way her successor, Anne Boleyn, cannot (II.ii.29-30).

This is at the opposite end of sophistication to a jewel we find at the opposite end of Shakespeare's writing life. In what may be his first play, The Two Gentlemen of Verona, we're told that 'Dumb jewels often in their silent kind / More than quick words do move a woman's mind' (III.i.90-1), where dumb jewels express a patriarchal desire for a dumb woman. Going back to Joan Evans's historical narrative, this is really the only example of the jewel as symbol

\footnotetext{
37 The equation of chastity and monetary possession in the symbol of the jewel is familiar in a number of Shakespearean studies. See, for example, Stephen Hannaford, "'My money is my daughter": Sexual and Financial Possession in English Renaissance Comedy', Shakespeare-Jahrbuch (Bochum, 1984), pp.93-110; Katherine Gillen, 'Chaste Treasures: Protestant Chastity and the Creation of a National Economic Sphere in The Rape of Lucrece and Cymbeline', Early English Studies 4 (2011), pp.1-38.
} 
of female luxury or subordination in Shakespeare, in contrast to the numerous instances of jewels as emblems of male valour or power.

The association of the jewel with the soul is an ancient one, although we struggle to find it explicitly made in any of the reading Shakespeare is known to have undertaken, whether Christian or Classical. Typically of Shakespeare, it features most prominently in a play not just about a lost soul, but the deliberate losing of a soul. Macbeth, having murdered his way to the throne, foresees a future in which his friend Banquo's offspring succeed him:

Upon my head they placed a fruitless crown

And put a barren sceptre in my grip,

Thence to be wrenched with an unlineal hand

No son of mine succeeding. If it be so,

For Banquo's issue have I filed my mind,

For them the gracious Duncan have I murdered;

Put rancours in the vessel of my peace

Only for them, and mine eternal jewel

Given to the common enemy of man... (III.i.60-8)

To damn yourself for nothing is worse than a Faustian bargain, and the soul he has traded in is stained ruby-red with blood. On the verge of suicide, Othello describes his fate in similar terms, asking to be compared to the 'base Indian' ('Judean' in an alternative reading) who 'threw a pearl away richer than all his tribe', in this case compressing his soul and his wife's chastity into a single pearl (V.ii.350-1). Macbeth's syntax is echoed by an Antony outraged at the sight of Caesar's messenger kissing Cleopatra's hand, and drawn in this case to the gem who is his legitimate wife as opposed to the damaged goods he now confronts:

You were half blasted ere I knew you. Ha! Have I my pillow left unpress'd in Rome, Forborne the getting of a lawful race, And by a gem of women, to be abus'd By one that looks on feeders? (III.xiii. 105-9)

Jewels in the plural exhibit a similar trajectory of loss, shared by the plural 'stones' when used as a synonym for 'jewels'. John Keats memorably identified in Shakespeare's works the power of what he called negative capability: the idea of doubt as a creative principle, often dramatized as 
consciously unorthodox or subversive thought, or simply, in the case in question here, as lack or absence where we expect plenty. ${ }^{38}$ Jewels in the plural drew from two of Shakespeare's contemporaries, Christopher Marlowe and Ben Jonson, the obvious theatrical excitement of extravagant display. Marlowe's The Jew of Malta begins with the eponymous hero, Barabas, 'in his counting house, with heaps of gold before him', and salivating over what more there is to come from 'merchants of the Indian mines' and 'wealthy Moor[s]':

Bags of fiery opals, sapphires, amethysts, Jacinths, hard topaz, grass-green emeralds, Beauteous rubies, sparkling diamonds, And seld-seen costly stones of so great price.... 39

The similarly voracious hero of Ben Jonson's Volpone greets the new day only to find it less dazzling than his accumulated riches:

Good morning to the day, and next my gold!

Open the shrine, that I may see my saint.

His servant Mosca promptly draws a curtain, 'revealing piles of gold.'40 The contrast with Shakespeare's evocations of plural jewels could not be starker.

Where Marlowe and Jonson stun us with their visual presence, Shakespeare makes poetry of their absence. Shylock, his response to Marlowe's Barabas, mourns the loss of his 'precious, precious jewels' and 'precious stones'. Henry VI, disguised and on the run, wears his crown in his heart only, 'not deck'd with diamonds and Indian stones' (III.i.63). In the nightmare before his murder in Richard III, the Duke of Clarence sees 'Unvalued jewels, / All scattered in the bottom of the sea' (I.iii.27-8) and therefore, unlike Barabas's opals and sapphires, beyond the reach of any merchant, a fittingly eerie metaphor for his own impending death. Only supernatural intervention could rescue them, as when Titania, Queen of the Fairies in A Midsummer Night's Dream, orders jewels

\footnotetext{
${ }^{38}$ Keats, Letter to George and Thomas Keats, 21 December 1817.

${ }^{39}$ Marlowe, The Jew Malta, in J.B. Steane, ed., Christopher Marlowe. The Complete Plays (Harmondsworth: Penguin, 1969), I.i.25-28; p.349.

40 Jonson, Volpone, in Michael Jamieson, ed., Ben Jonson. Three Comedies

(Harmondsworth: Penguin, 1966), I.i.1-2; p.51.
} 
to be fetched 'from the bottom of the sea' (III.i.144). Jewels as people feature grimly when Cordelia, in King Lear, bids farewell to the sisters she knows will go on cheating the old king, describing them bitterly as 'the jewels of our father', fakes in the marketplace of discourse (I.i.268). Gloucester's eye-sockets are empty, 'their precious stones now lost' (V.iii.190). The battle-hardened Titus Andronicus mourns his dead sons only as 'jewels purchased at an easy price', and therefore the easier to give up (III.i.199).

Shakespeare's negative capability draws us to the miseries and mysteries of loss and unpossession: of the 'unvalued', the fake, the cheap. But this is not just about what it is like to have lost them but - arguably far worse - to have lost faith in them: a concern activated no less by scandals in the Goldsmiths' Company than by the iconoclasm of the Reformation itself. The exception that proves the rule is the 'stones of worth' in Sonnet 52, kept secret for 'feasts so solemn and so rare' rather than surveyed 'ev'ry hour': these are relics jealously guarded, kept under lock and key. It is perhaps over-prescriptive to find in jewels, as do the compilers of the Penguin Dictionary of Symbols, a metaphor that distinguishes English from French dramatic tradition:

Jewels are endowed with a secret of immortality which does not come from the gods but from the bowels of the Earth. As a result, the ambitions, passions and worship which they arouse suggest the ambience of Shakespearean drama rather than that of Racinian tragedy. ${ }^{41}$

However, consideration of their pervasive citation in Shakespeare's work suggests a writer for whom jewels subconsciously distilled something more than the politics of Eros. In their 'secret', whether of real or false value, he found a nation's making and unmaking.

Based on a lecture given on 14 May 2015 to celebrate the $125^{\text {th }}$ anniversary of the Birmingham School of Jewellery.

\footnotetext{
41 Jean Chevalier and Alain Gheerbrandt, trans. John Buchanan-Brown, The Penguin Dictionary of Symbols (Harmondsworth: Penguin, 1996), p.554.
} 